\title{
Mechaniczne opory tarcia występujące w cylindrach hamulcowych pojazdów szynowych
}

\begin{abstract}
W artykule omówiono wyniki wstępnych badań dotyczace określenia mechanicznych oporów tarcia wystepujacych $w$ kolejowych cylindrach hamulcowych. W czasie pracy cylindra hamulcowego jego tłok uszczelniany jest uszczelka gumowa smarowanq smarem stalym, dociskanq ciśnieniem powietrza wewnatrz cylindra. Celem badań było określenie wartości liczbowych oporu ruchu tłoka, wykorzystanych następnie $w$ modelu matematycznym. Dokonano pomiarów sil tarcia różnych cylindrów z różnymi parametrami pracy $i$ zaprezentowano wyniki.

Artykut powstat w wyniku realizacji projektu badawczego KBN nr 5 T12C03025 pt. „Badania procesów zachodzacych w pneumatycznych uktadach hamulcowych pociagów".
\end{abstract}

\section{Wstęp}

Działanie pneumatycznego układu hamulca kolejowego z punktu widzenia wytworzenia efektywnej siły na trzonie tłoka cylindra można podzielić na 3 fazy:

- wysterowanie odpowiedniego ciśnienia hamowania w zaworze rozrządczym

- dostarczenie sprężonego powietrza do cylindra

- zamiana ciśnienia sprężonego powietrza w cylindrze hamulcowym na siłę mechaniczną $z$ uwzględnieniem strat i przeniesienie jej na elementy cierne hamulca.

Siła działająca na elementy cierne układu hamulcowego, w porównaniu $\mathrm{z}$ teoretyczną siłą tłokową cylindra (wynikającą z iloczynu ciśnienia w cylindrze przez pole powierzchni tłoka) przemnożoną przez przełożenie układu dźwigniowego, obarczona jest stratami. Straty te wynikają z przeciwdziałania elementów sprężystych (głównie siły sprężyny umieszczonej wewnątrz cylindra) oraz $\mathrm{z}$ tarcia elementów ruchomych układu mechanicznego. Straty te są uwzględniane w obliczeniach układu hamulcowego poprzez współczynnik sprawności. Dla dokładnej analizy działania pneumatycznego układu hamulca wagonu (np. niezbędnej do jego matematycznego modelowania) powinno się uwzględniać właściwości reologiczne układu ruchowego cylindra hamulcowego.

Prezentowany artykuł stanowi próbę określenia mechanicznych oporów występujących w cylindrze hamulcowym w czasie jego pracy poprzez pomiary na obiekcie rzeczywistym.

Do badań użyto kolejowych cylindrów hamulcowych wyprodukowanych w Zakładzie Budowy Maszyn OSINY, o średnicach tłoka 14" i 9". Na rys. 1 przedstawiono przykładowy przekrój cylindra.

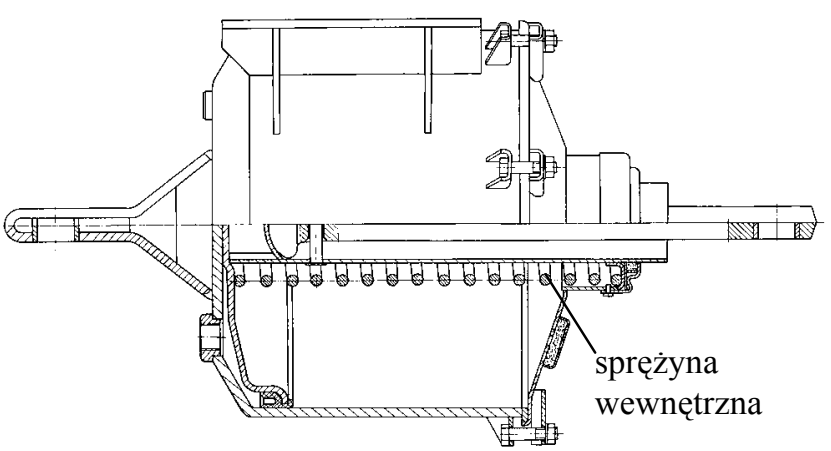

Rys.1. Przekrój kolejowego cylindra hamulcowego

Mechaniczne opory występują w cylindrze hamulcowym przy przesuwie tłoka, głównie na skutek tarcia uszczelnienia tłoka o ścianki cylindra. Gumowe uszczelnienie tłoka ma kształt wargowy. Jest dociskane do powierzchni roboczej cylindra siłami własnej sprężystości i dodatkowo parciem powietrza $\mathrm{w}$ czasie pracy, co powoduje zmienność sił tarcia $\mathrm{w}$ funkcji ciśnienia powietrza w cylindrze. Para cierna cylinderuszczelka (rys. 2) jest smarowana smarem stałym, nałożonym przeważnie w dużej ilości. W trakcie eksploatacji ulega on zgarnianiu, starzeniu, może także chłonąć wodę skraplaną ze sprężonego powietrza. Dodatkowo wielkość oporów zależy również od temperatury zewnętrznej i stanu zanieczyszczenia cylindra. Stan smarowania cylindra jest więc w znacznej mierze nieokreślony.

Drugim elementem powodującym tarcie w trakcie ruchów tłoka jest tarcie pomiędzy trzonem rurowym, a uszczelnieniem przeciwpyłowym, stanowiącym prowadzenie tłoka. Ta siła tarcia osiaga dużo mniejsze wartości, niż tarcie o ścianki cylindra. Obie te siły będą rozpatrywane łącznie. 


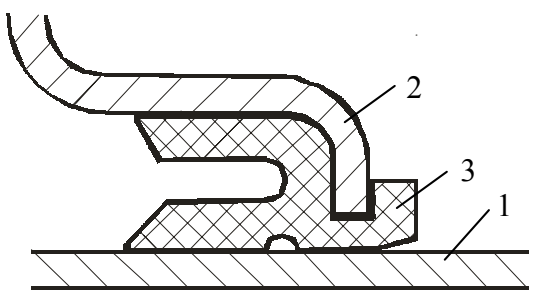

Rys.2. Przekrój uszczelnienia tłoka 1- cylinder, 2 - tłok, 3 - uszczelnienie wargowe

W opracowanej metodzie symulacyjnej analizy całopociągowego układu pneumatycznego hamulca kolejowego utworzono kilka modeli cylindra kolejowego, z możliwością wykorzystania różnorodnych modeli tarcia $[1,3,4]$. Nie posiadano jeszcze danych liczbowych dotyczących histerezy cylindra kolejowego. Analizy opisane w niniejszym artykule posłużą w kolejnym etapie do weryfikacji modeli oraz identyfikacji parametrów modelu na podstawie wyników doświadczalnych. Są one częścią identyfikacji całego układu hamulca pneumatycznego [5]. Ze względu na ograniczony zakres badań i posiadaną aparaturę, opracowanie służy do rozpoznania zjawisk, a nie do dokonania dogłębnej analizy. Poza tym pewna nieokreśloność stanu nasmarowania cylindra, wynikająca z eksploatacji w różnych warunkach, czyni dokładniejsze analizy mało przydatnymi.

Zagadnieniami, które określono w artykule są:

- rozróżnienie siły tarcia statycznego od tarcia ruchowego (Coulomba)

- poziom siły tarcia ruchowego i jej zmienność w funkcji ciśnienia $\mathrm{w}$ cylindrze

- zmienność siły tarcia w funkcji prędkości przesuwu tłoka

- skrócona analiza wpływu rodzaju smaru na współczynnik tarcia w cylindrze.

\section{Stanowisko badawcze i metody pomiaru}

Schemat stanowiska badawczego podano na rys. 3. Dla celów badawczych wykorzystano:

- pneumatyczną aparaturą zasilająca

- badany układ cylindra

- czujniki ciśnienia i przemieszczeń

- cyfrową aparaturę rejestrująca.
Rejestrowane i przedstawione wartości ciśnień są nadciśnieniami, mierzonymi $\mathrm{w}$ barach, od ciśnienia atmosferycznego. Przemieszczenia podano w centymetrach,. Przyjęte jednostki wynikały z zastosowanego w badaniach układu pomiarowego. Wielkości sił występujących w cylindrze, również sił tarcia, określono $\mathrm{w}$ jednostkach ciśnienia powietrza $\mathrm{w}$ cylindrze. Jest to związane z przyjętym sposobem modelowania całego układu pneumatycznego opartym o wartości ciśnienia w objętościach układu.

Sztywne ograniczenie ruchu tłoka dla dużych ciśnień nie pozwoliłoby na analizę sił tarcia, dlatego w badaniach zastosowano dodatkowe sprężyny śrubowe umieszczone na zewnątrz cylindra, pomiędzy trzonem tłoka, a ogranicznikiem jego ruchu. Pozwoliło to przy większych ciśnieniach w cylindrze uzyskać możliwość (niewielkiego) przemieszczania się tłoka, zamiast przylgnięcia trzona tłoka do odbijaka. $\mathrm{Z}$ powodu niewielkich prędkości tłoka założono, że histereza i thumienie sprężyn są pomijalnie małe $\mathrm{w}$ porównaniu $\mathrm{z}$ tarciem tłoka i nie uwzględniono ich.

Pomiarów dokonano zarówno w zakresie niewielkich ciśnień w cylindrze (i braku sprężyny zewnętrznej), jak i w zakresie większych ciśnień spotykanych w eksploatacji, z użyciem sprężyn zewnętrznych. Łącznie dokonano pomiarów $\mathrm{z}$ użyciem następujących wariantów sprężyn:

1. Tylko sprężyna wewnętrzna ( o sztywności ok. $4,2 \mathrm{kN} / \mathrm{m}$ ).

2. Zamontowana z luzem wstępnym sprężyna słabsza ( o sztywności ok. $257 \mathrm{kN} / \mathrm{m}$ ). W zakresie małych przemieszczeń tłoka i ciśnień (dla cylindra 14" do ok. 0,14 bar) ściskana jest tylko sprężyna wewnętrzna, dla ciśnień większych obie sprężyny. Dla cylindra 9" analizowano układ bez luzu.

3. Zamontowana $\mathrm{z}$ napięciem wstępnym sprężyna nazwana sztywniejszą ( sztywności ok. 286 $\mathrm{kN} / \mathrm{m}$ ). W całym zakresie ciśnień pracuje sprężyna wewnętrzna i zewnętrzna. Napięcie wstępne zastosowano, by w ramach dopuszczalnego skoku tłoka (limitowanego skokiem czujnika przemieszczenia) uzyskać maksymalne siły w cylindrze.

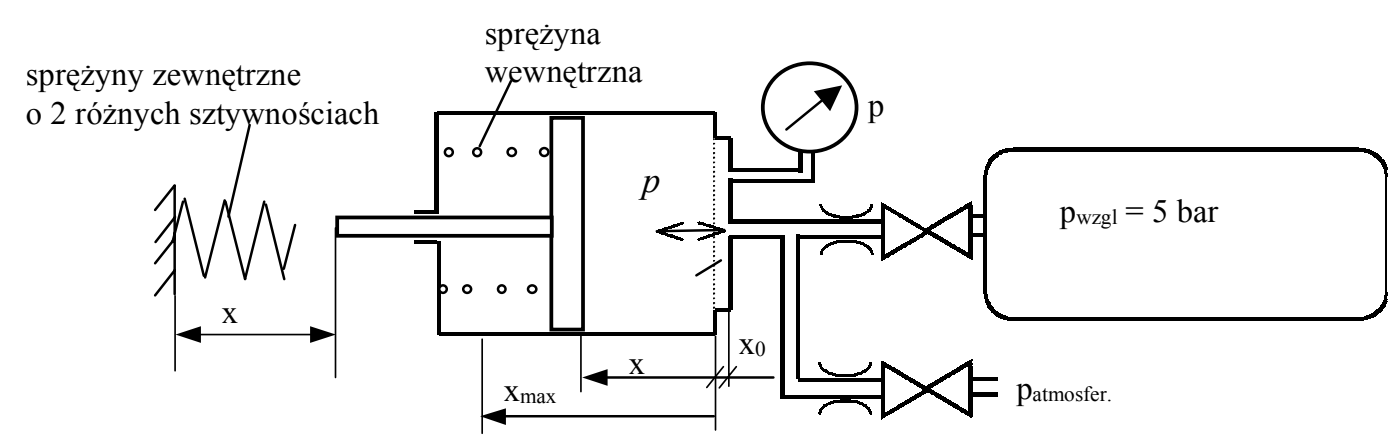

Rys. 3. Schemat stanowiska badawczego układu $\mathrm{x}_{0}$-skok martwy, $\mathrm{x}$-przesuw tłoka, $\mathrm{x}_{\max }$ - przesuw maksymalny, $\mathrm{p}$ - ciśnienie w cylindrze 
W celu zamocowania sprężyny zewnętrznej usunięto ucho $\mathrm{z}$ trzona tłoka i wprowadzono jego centrowanie, służące również do mocowania sprężyny i czujnika przemieszczenia.

Zakres prędkości wysuwania się tłoka był różny i zadawany dławieniem przepływu $\mathrm{w}$ regulowanych, stałych $\mathrm{w}$ trakcie pomiaru przelotach zaworów do- $\mathrm{i}$ wylotowego. Dla określenia współczynnika tarcia statycznego prędkość tłoka po jego ruszeniu była rzędu $0,1 \mathrm{~mm} / \mathrm{s}$, a dla oszacowania siły tarcia w funkcji prędkości tłoka $\mathrm{w}$ zależności od rodzaju cylindra maksymalnie rzędu $450 \mathrm{~mm} / \mathrm{s}$. Przy próbach z większymi prędkościami ruchu tłoka zdemontowano filtr odpowietrzania strony swobodnej tłoka i zwiększono przeloty jego otworów, by nie powstawało nadciśnienie zmieniające wyniki pomiarów. Przy pomiarach zjawisk szybkozmiennych czujnik ciśnienia zamontowano bezpośrednio $\mathrm{w}$ cylindrze na dodatkowym króćcu, a nie na przewodzie, likwidując możliwość zafałszowania wyników z powodu strat przepływu.

Pomiarów dokonywano trzema metodami.

Metoda I

Polegała na powolnym zwiększaniu lub zmniejszaniu ciśnienia w cylindrze przy pierwotnie nieruchomym tłoku. Zaletą tej metody była możliwość dłuższego zatrzymania tłoka, ale wadą to, że w czasie dłuższego zatrzymania tłoka ciśnienie powietrza $\mathrm{z}$ powodu zmiany temperatury gazu mogło się zmieniać i tworzyć dodatkowe, niezaplanowane w eksperymencie naprężenie w uszczelnieniu tłoka. Wadą było też to, że nie można było uzyskać dokładnie tej samej współrzędnej przemieszczenia tłoka przy początku ruchu w obu kierunkach. Metodę tę wykorzystano do badań wstępnych.

Metoda II

Aby uniknać wad pomiarów metody I dokonano pomiarów następującej sekwencji:

1 - wzrost ciśnienia i wysuwanie tłoka

2 - spadek ciśnienia - zatrzymanie tłoka i jego cofanie

3 - wzrost ciśnienia - zatrzymanie tłoka i ponowne jego wysuwanie.

Zatrzymanie wysuwu tłoka było krótkotrwałe, zależne od histerezy ruchu tłoka, bez nieokreślonej fazy zmian ciśnienia. Pomiarów dokonano dla niewielkich prędkości ruchu tłoka (rzędu jednego $\div$ kilkunastu $\mathrm{mm} / \mathrm{s}$ ) oraz regulowanej przepustowości zaworów przepływu powietrza do i z cylindra.

Metoda III

Dla określenia wpływu prędkości poruszana się tłoka na wartość siły tarcia dokonywano jednorazowego pełnego wysuwu lub cofania tłoka $\mathrm{z}$ różnymi prędkościami, gdyż przerywanie ruchu tłoka dla dużych prędkości byłoby utrudnione. Wyniki analizowano dla wybranych wysuwów tłoka (i odpowiadających im ciśnień).

\section{Rozróżnienie sily tarcia statycznego od tarcia ruchowego}

Dla oszacowania różnicy między tarciem statycznym i ruchowym (Coulomba) dokonywano pomiarów metodą I. Analizowano wykresy przemieszczania tłoka w cylindrze w funkcji ciśnienia (przykładowe przebiegi przedstawiono na rys. 4 i 5).

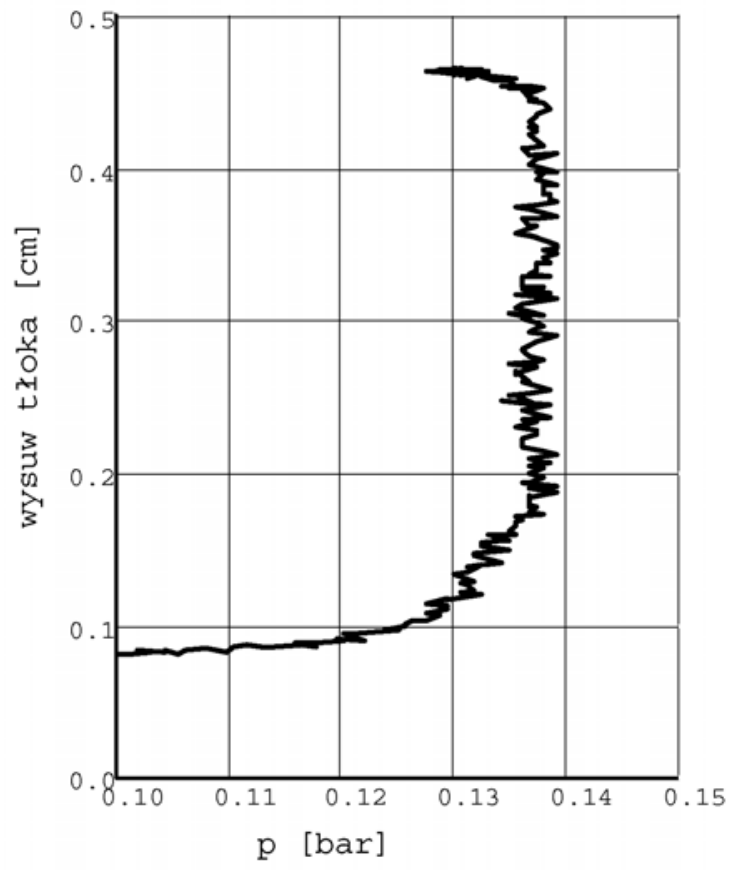

Rys. 4. Przykład wysuwania tłoka po stanie jego bezruchu

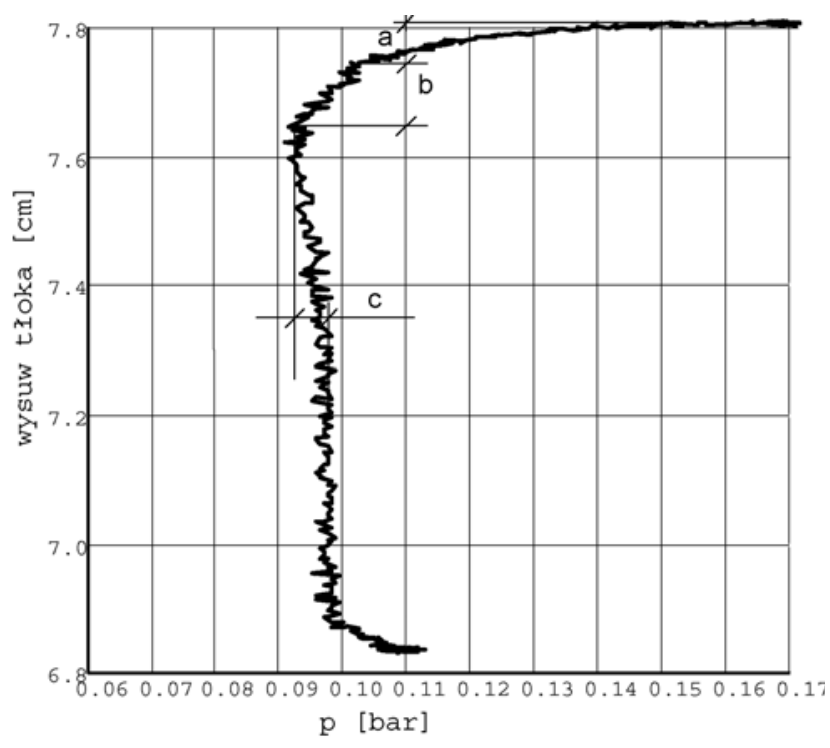

Rys. 5. Przykład cofania tłoka po stanie jego bezruchu a - sprężystość układu, b - deformacja uszczelki, c - wzrost tarcia statycznego

$\mathrm{Na}$ rys. 5 nie widać różnicy między tarciem statycznym a ruchowym. Na rysunku 6 widoczne są zjawiska zidentyfikowane jako ugięcie sprężyste uszczelnienia i różnica między ciśnieniem w warunkach tarcia statycznego i ruchowego. 


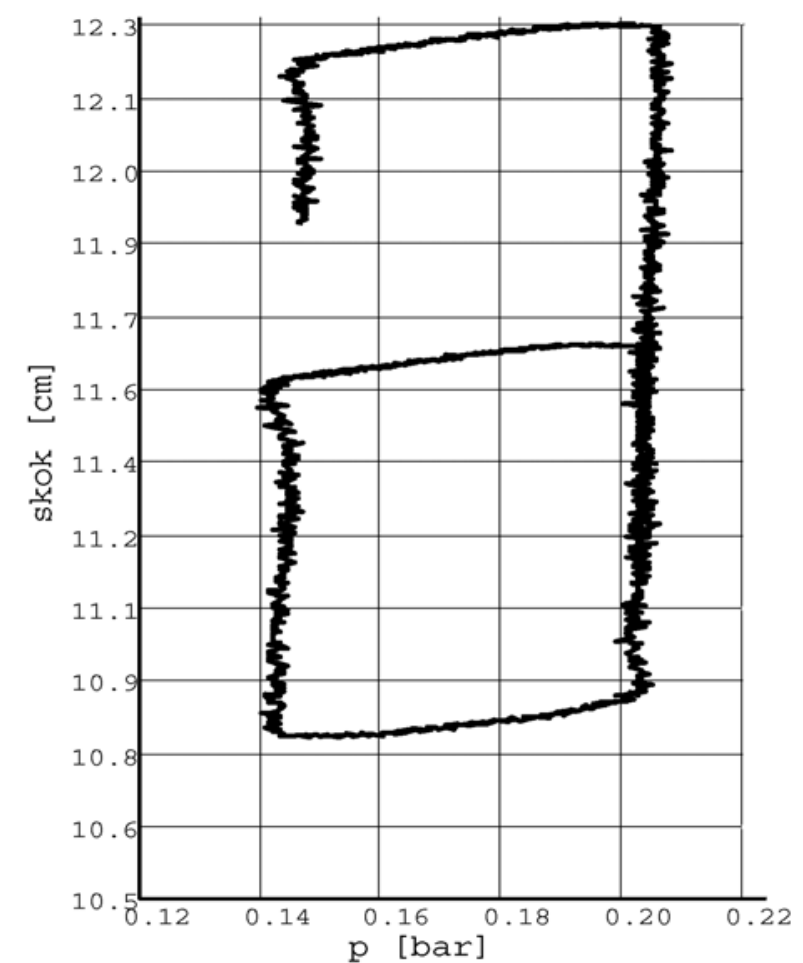

Rys. 6. Przykład pojedynczego pomiaru histerezy pomierzony metodą II

Na rysunku 6 przedstawiono przykładowy wynik pomiaru dokonanego metodą II. Uzyskiwano dużą dokładność zamknięcia się pętli. Z każdego wykresu odczytywano ciśnienia zatrzymania i ruszania tłoka oraz ciśnienia dla obu kierunków ruchu dla wybranego przemieszczenia tłoka $\mathrm{w}$ ustabilizowanej części ruchu. Pomiarów dokonywano w całym możliwym zakresie, aż prawie do blokowania sprężyn zewnętrznych.

Różnica miedzy tarciem statycznym a ruchowym dla większych histerez uwidaczniała się często w postaci niewielkich ruchów oscylacyjnych: ruszania i zatrzymywania się tłoka. Występowanie oscylacji zależy od omawianej różnicy sił tarcia, od sztywności szeregowych pomiędzy tłokiem, a powierzchnią cierną (sprężystości uszczelki) i sztywności pneumatycznego wzbudzania ruchu tłoka. Zagadnienie to nie będzie dalej rozpatrywane. Wartość zmian ciśnienia w cylindrze w trakcie oscylacji w większości przypadków nie była większa, niż 0,02 bar, a jej poziom był podobny do wykazanego $\mathrm{w}$ trakcie nie oscylacyjnego ruszania tłoka. W skrajnych przypadkach i ruchów oscylujących zmiana ciśnienia osiagała wartości 0,05 bar, jednakże w tym przypadku na podstawie różnych pomiarów można przypuszczać, że wartość ta nie odzwierciedla wzrostu tarcia spoczynkowego, ale jest powiększona o zjawiska dynamiki ruchu tłoka.

W większej części pomiarów dokonanych w obu kierunkach ruchu brak było oscylacji i wzrost tarcia statycznego okazał się bardzo niewielki i nieregularny; wynosił on przeciętnie od 0 do 0,02 bar, skrajnie 0,05 bar; w pomiarach ze sprężynami zewnętrznymi wzrost tarcia był praktycznie niezauważalny.
Różnica ta jest niewielka i dla kilku pomiarów osiaga maksymalnie 5\% siły tarcia. Dla normalnych pomiarów układu hamulcowego nie przekroczy zapewne błędu pomiarowego. $\mathrm{W}$ związku $\mathrm{z}$ tym nie będzie szczegółowiej rozpatrywana.

$\mathrm{Na}$ wykresach widoczne są dodatkowe elementy zjawiska:

- niewielkie poczattkowe przemieszczenie tłoka wywołane najprawdopodobniej sztywnością układu pomiarowego, przemianami termicznymi powietrza $\mathrm{i}$ resztkowym uginaniem uszczelki, osiagające $\mathrm{w}$ ciagu kilku sekund wartość kilku dziesiątych milimetra,

- deformacja uszczelki bez przemieszczenia na powierzchni styku z cylindrem, osiaggająca dla obu kierunków ruchu wartość średnią po ok. $1 \mathrm{~mm}$.

\section{Określenie siły tarcia ruchowego w funkcji ciś- nienia $\mathbf{w}$ cylindrze}

Do dalszych analiz wykorzystano wstępny wynik badań, tzn. że różnica między tarciem spoczynkowym i ruchowym jest bardzo niewielka.

Budowa uszczelnienia tłoka $\mathrm{z}$ wargowym występem (rys. 2) powoduje zmienność siły tarcia w zależności od ciśnienia w cylindrze, dlatego też dalsze prezentacje wyników będą odniesione do ciśnienia nominalnego w cylindrze, które wybrano jako średnie dla wysuwania się i cofania tłoka.

Na rysunkach 7 i 8 przedstawiono dla zobrazowania zjawiska tarcia przebieg ciśnienia w cylindrze w trakcie wysuwania i cofania tłoka.

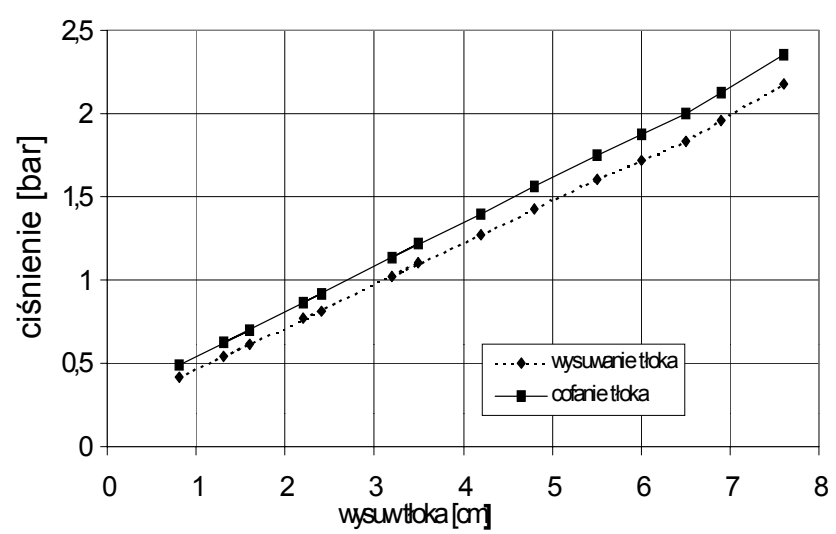

Rys. 7. Przebieg ciśnienia w cylindrze 14" ze sztywniejszą sprężyną zewnętrzną, cylinder ze świeżym smarem ŁT43

Z przetworzonych wyników pomiarów określano histerezę przesuwania się tłoka (rozumianą jako różnicę ciśnienia między wysuwaniem a cofaniem tłoka) w funkcji ciśnienia w cylindrze. Wykresy wyników dla różnych konfiguracji badań przedstawiono na rysunkach 9 do 13. Pomiarów dokonywano dla różnych celów poznawczych i nie zawsze są one kompatybilne między sobą. Niepełna regularność wyników spowodowana jest tym, że prezentowane wartości są przetworzonymi wynikami $\mathrm{z}$ różnych pomiarów $\mathrm{i}$ błędy pojedynczych pomiarów mogą się sumować. 
Połączenia punktów na wykresach służą jedynie do lepszej wizualizacji wyników.

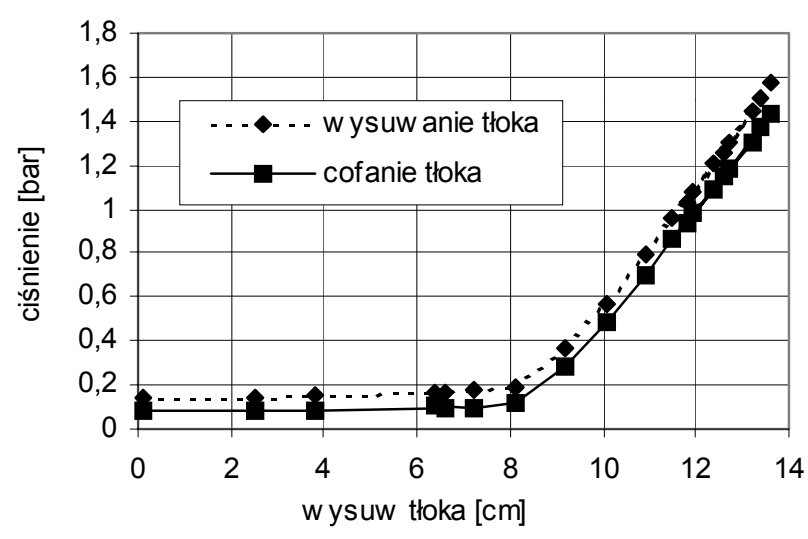

Rys. 8. Przebieg ciśnienia w cylindrze 14" ze słabszą sprężyną zewnętrzną i posiadającą początkowy luz, cylinder ze świeżym smarem ŁT43

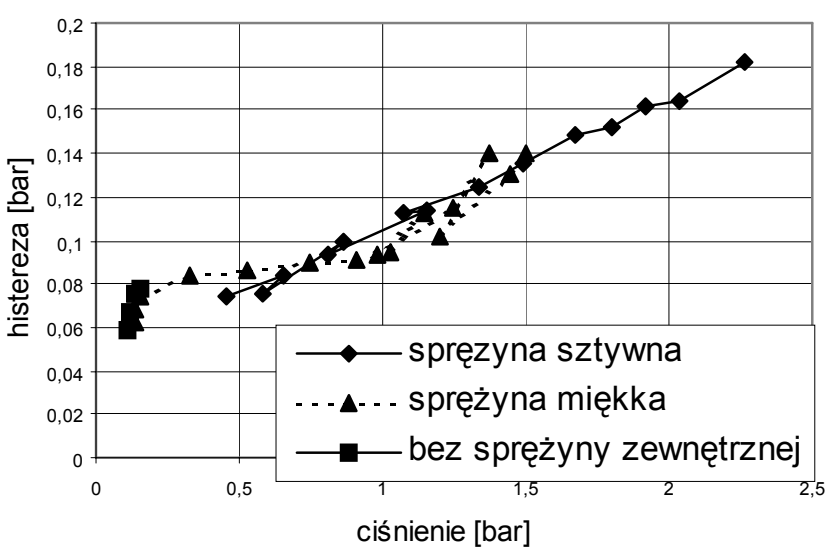

Rys. 9. Zmienność histerezy tarcia dla różnych układów sprężyn, cylinder 14" ze świeżym smarem ŁT43

Wartości histerezy okazały się niezależne od zastosowanego układu sprężyn, co przedstawia przykładowo rys. 9. Stwierdzenie to umożliwia łączenie wyników dla różnych sprężyn wykorzystanych w pomiarach.

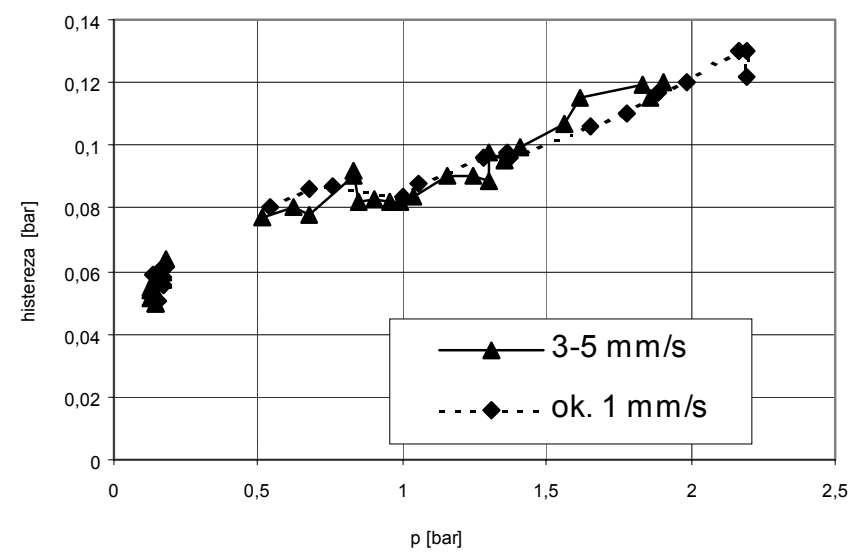

Rys. 10. Zmienność histerezy tarcia dla różnych prędkości ruchu tłoka, cylinder 14" ze starym smarem, różne sprężyny

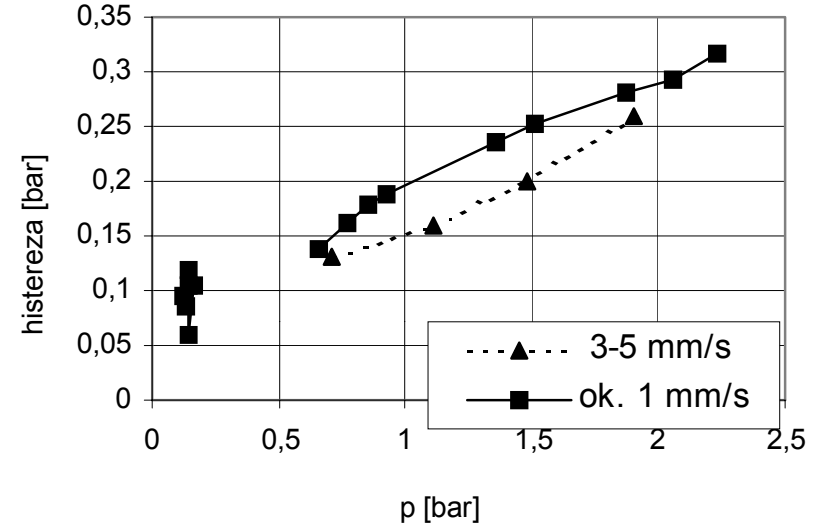

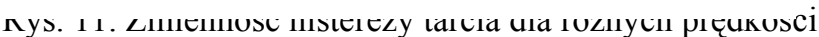
ruchu tłoka, cylinder 14 " ze smarem ŁT43 po rocznej eksploatacji

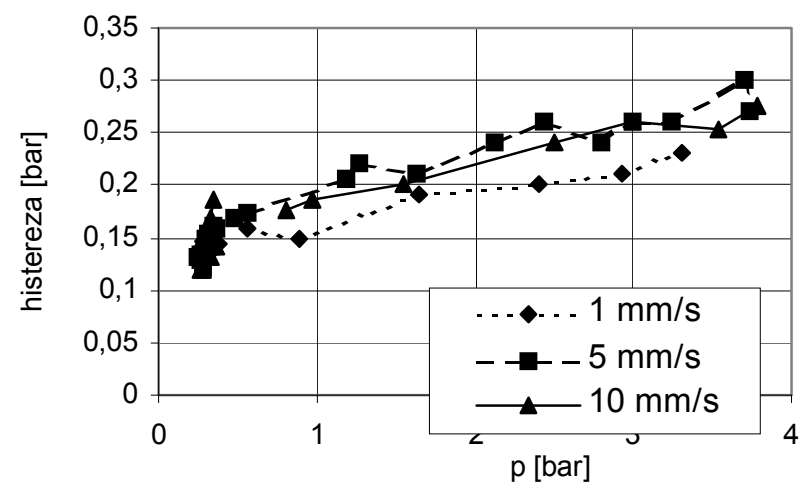

Rys. 12. Zmienność histerezy tarcia dla różnych prędkości ruchu tłoka, cylinder 9" ze starym smarem

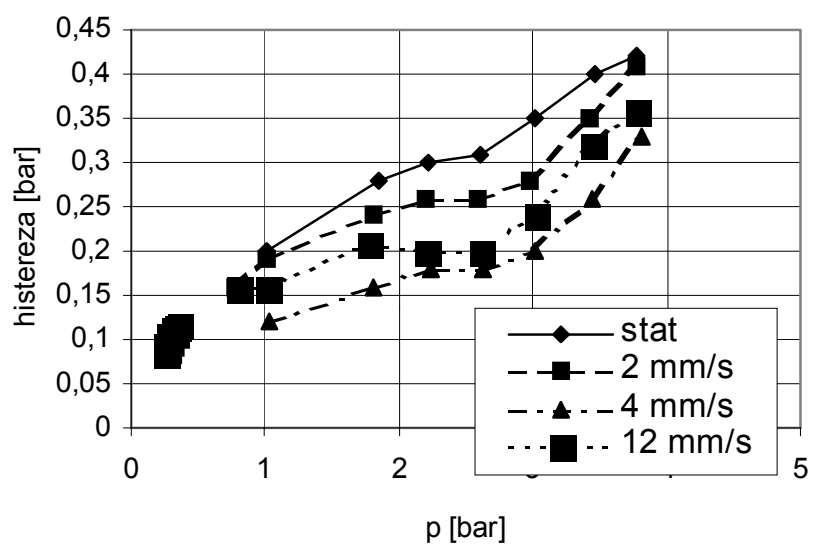

Rys. 13. Zmienność histerezy tarcia dla różnych prędkości ruchu tłoka, cylinder 9" ze smarem nowym Vecolit EPX-00

Jak wynika z przedstawionych wyników pomiarów, siła tarcia jest zmienna $\mathrm{w}$ funkcji ciśnienia $\mathrm{w}$ cylindrze. Zależność jest $\mathrm{w}$ przybliżeniu liniowa, $\mathrm{z}$ przesunięciem punktu zerowego spowodowanym wstępną siłą wciśnięcia uszczelnienia, osiagając do kilkunastu procent siły roboczej cylindra. Dla zerowego nadciśnienia w cylindrze wartość ciśnienia histerezy osiagnęłaby średnio dla cylindra 9" ok. $0,08 \div 0,13$ bar, a dla cylindra 14 " $0,05 \div 0,08$ bar. Ze względu na dużą zależność siły tarcia od stanu układu mechanicznego (głównie od stanu smaru) nie prowadzono analiz statystycznych. 
Większe wartości histerezy dla cylindra o średnicy 9" w porównaniu z cylindrami 14 " wynikaja z większego stosunku długości obwodu (i docisku) uszczelki do pola powierzchni cylindra (dla 9" wynosi on $17,5[1 / \mathrm{m}\rceil$, a dla 14 " $11,25[1 / \mathrm{m}\rceil)$.

\section{Zmienność sily tarcia w funkcji prędkości prze- suwu tloka}

Część układów ciernych, zwłaszcza z obfitym smarowaniem, wykazuje po początkowym spadku współczynnika tarcia (z wzrastającą prędkością ruchu) ponowny wzrost współczynnika tarcia dla większych prędkości. Spowodowany jest on wzrostem naprężeń wewnątrz smaru wywołanych efektem hydrodynamicznym (efekt Stribecka [2]). Dla zbadania przebiegu tego zjawiska w przypadku cylindra hamulcowego dokonano dalszych uproszczonych analiz.

$\mathrm{Z}$ wykresów rys. 10 do 13 wynika, że dla małych prędkości tłoka zależność siły tarcia od prędkości nie jest regularna i jest zależna od stanu smaru. Większą regularność pomiarów uzyskano z użyciem smaru półpłynnego (Vecolit EPX-00) dla cylindra 9", co przedstawiono na rys. 13.

Największej ilości prób metodą III dokonano dla cylindra 9" i te wyniki zaprezentowano.

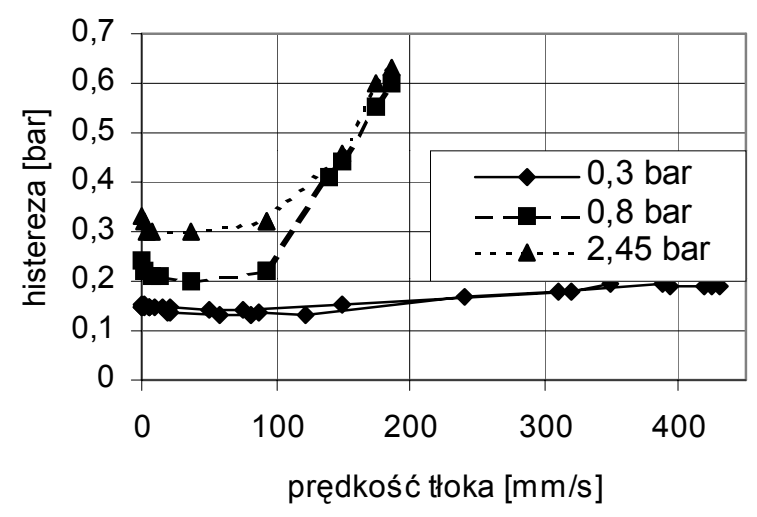

Rys. 14. Zmienność histerezy tarcia dla różnych prędkości ruchu tłoka, cylinder 9" ze smarem starym

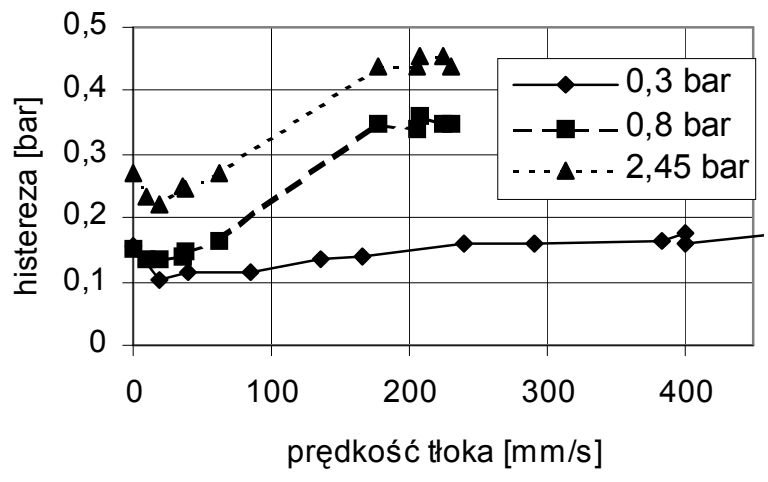

Rys. 15. Zmienność histerezy tarcia dla różnych prędkości ruchu tłoka, cylinder 9" ze świeżym smarem

Vecolit EPX-00
Na rys. 14 i 15 przedstawiono zależność histerezy wywołanej tarciem uszczelnienia tłoka cylindra od prędkości ruchu tłoka. Wyniki zaprezentowano dla wybranych ciśnień w cylindrze. Wyniki dla wartości średniej nadciśnienia 0,3 bar uzyskano bez sprężyny zewnętrznej, a 0,8 bar i 2,45 bar z dodatkową sprężyną zewnętrzna. Wyniki wskazują na istotny wzrost współczynnika tarcia (i histerezy) dla większych prędkości ruchu tłoka. Wzrost ten jest istotniejszy dla większych ciśnień w cylindrze. Wartość histerezy, jak i jej wzrost jest nieco większy dla starego smaru, który był gęstszy. Znaczniejszy wzrost tarcia następuje jednak dopiero dla prędkości tłoka większych, niż występujące w układzie hamulcowym. Na przykład przed przylgnięciem par ciernych swobodny tłok (ciśnienie w cylindrze $\mathrm{z}$ uwzględnieniem tarcia ok. 0,3 bar) maksymalna prędkość tłoka podczas hamowania nagłego wynosi około $200 \mathrm{~mm} / \mathrm{s}$, a przy większych ciśnieniach jest dużo mniejsza. Maksymalna prędkość w trakcie pomiarów (rys. 14 i 15) była więc zawsze dużo większa, niż w trakcie eksploatacji hamulca. Zaprezentowane wyniki świadczą o tym, że w zakresie normalnej pracy cylindra nie występuje w nim znaczący, konieczny do uwzględnienia w modelu, dodatkowy wzrost tarcia zależny od prędkości ruchu tłoka.

\section{Zmienność sil tarcia dla różnych stanów na- smarowania cylindra}

Zmienność histerezy tarcia $\mathrm{w}$ cylindrze analizowano (wybiórczo) również w zależności od rodzaju użytego smaru. Nie prowadzono analiz dotyczących ilości smaru, gdyż normalnie jest on nakładany w znacznej ilości, a w czasie eksploatacji rozmieszczany w nieokreślony sposób wewnątrz cylindra.

W trakcie pomiarów wykorzystano następujące rodzaje smarów (w nawiasie podano, w którym cylindrze zastosowano):

- stary smar wieloletni (nieokreślony, zawarty przed pomiarami w wykorzystanych cylindrach 9" i 14"), był on gęstszy, niż zastosowane świeże smary i w większości zgromadzony na niepracujących powierzchniach cylindra

- smar stały ŁT-43 świeży (cylinder 14”); posiada on konsystencję (współczynnik penetracji $260 \div 300$ ) nieco rzadsza, niż stary smar

- smar stały ŁT-43 po rocznej eksploatacji na stanowisku pomiarowym (cylinder 14")

- półpłynny smar świeży Vecolit EPX-00 (współczynnik penetracji 420) zalecany z powodu odporności: temperaturowej i na działanie wody (cylinder 9").

Wyniki pomiarów dla różnych smarów przedstawiono na rys. 10 do 13 . Wynikają $\mathrm{z}$ nich następujące spostrzeżenia: 
- stary smar w cylindrach nie wykazywał znacznie gorszych, niż smary świeże, właściwości smarnych, pomimo kilkunastoletniej eksploatacji na stanowisku badawczym

- cylinder 14" ze świeżym smarem ŁT43 nie wykazywał lepszej charakterystyki, niż ze starym smarem w cylindrze

- cylinder 14" ze smarem ŁT43 po rocznej eksploatacji wykazał znacznie większą histerezę, niż smar ŁT-43 świeży lub stary zastany w cylindrze, zwłaszcza dla większych ciśnień w cylindrze, osiagając histerezę do $15 \%$ ciśnienia w cylindrze ( prawie dwukrotnie większą, niż w innych przypadkach); spowodowane jest to najprawdopodobniej częściowym usunięciem smaru $\mathrm{z}$ powierzchni tarcia i zmianami chemicznymi z powodu zawilgocenia smaru $\mathrm{w}$ trakcie eksploatacji

- smar świeży półpłynny Vecolit EPX-00 wykazuje mniejszą histerezę, niż gęstszy smar stary (czego należało się spodziewać).

Problematyka rodzaju smaru wymaga dalszych badań.

\section{Wnioski}

Przedstawione analizy dokonane na podstawie przeprowadzonych różnorodnych pomiarów doświadczalnych ważne są dla konkretnych cylindrów hamulcowych, jednakże na ich podstawie można wstępnie określić następujące uogólnione zależności siły tarcia dla cylindra hamulcowego:

- siły tarcia statycznego w cylindrze osiagają wartości pozwalające określić je jako istotne, gdyż w niekorzystnych przypadkach mogą osiagnąć ok. 15 $\%$ siły pneumatycznej w cylindrze

- histereza tarcia dla większych ciśnień w cylindrze osiagała wartości $6 \div 15 \%$ ciśnienia w cylindrze, co w uproszczeniu daje sprawność cylindra rzędu 97 $\div 92,5 \%$ stanowiąc istotną część spadku sprawności całego układu hamulcowego

- zmienność siły tarcia $\mathrm{w}$ funkcji ciśnienia $\mathrm{w}$ cylindrze jest znaczna, zmienia się ona $\mathrm{w}$ przybliżeniu liniowo wraz $\mathrm{z}$ ciśnieniem $\mathrm{w}$ cylindrze, posiadając równocześnie niezerową wartość początkową siły tarcia dla nadciśnienia zerowego. Wartość ta zależy od średnicy cylindra. Wartość histerezy dla cylindra 9" i zerowego nadciśnienia osiagnęła wartość $0,08 \div 0,13$ bar, a dla nadciśnienia 3 bar ok. $0,2 \div 0,35$ bar; nie wykazano jednoznacznej zależności tarcia od stanu smaru we wnętrzu cylindra
- siła tarcia ruchowego (Coulomba) różni się od siły tarcia statycznego bardzo niewiele, nie pozwalając przy tych uproszczonych badaniach na jej ujęcie statystyczne; dla symulacji cylindra różnica jest nieistotna, natomiast może ona spowodować powstanie niewielkich oscylacji ruchu tłoka

- zmienność siły tarcia w funkcji prędkości przesuwu troka $\mathrm{w}$ zakresie roboczych prędkości przesuwu tłoka jest wykrywalna, jednakże mało istotna dla analiz układu hamulcowego, natomiast jest bardziej istotna dla większych prędkości tłoka poza zakresem spotykanym w układach hamulca kolejowego.

\section{Literatura}

[1] Gasowski W., Piechowiak T.: Matematyczny opis zjawisk zachodzacych w układzie pneumatycznym hamulca pociagu. Pojazdy Szynowe, nr 1/2004.

[2] Olsson H., Aström K.J., Canudas de Wit C., Gäfvert M., Lischinsky P.: Friction Models and Friction Compensation. European Journal of Control, $n r 4 / 1998$.

[3] Piechowiak T.: Metoda matematycznego modelowania ukladu pneumatycznego hamulca pojazdu szynowego. Pojazdy Szynowe, nr 3/2005.

[4] Piechowiak T.: Metody modelowania pracy zaworów rozrzadczych pojazdów szynowych. Pojazdy Szynowe, $n$ r 1/2006.

[5] Piechowiak T.: Weryfikacja modeli symulacyjnych pneumatycznego hamulca kolejowego pomiarami doświadczalnymi. XVII Konf. Nauk. POJAZDY SZYNOWE 2006, Warszawa 2006. 